Editorial

\title{
Authoritarianism in the 21st Century
}

\author{
Natasha Ezrow \\ Government Department, University of Essex, Colchester, CO4 3SQ, UK; E-Mail: nezrow@essex.ac.uk
}

Submitted: 6 June 2018 | Published: 22 June 2018

\begin{abstract}
This introduction offers an overview of the key works in this edited volume on authoritarian regimes. This edited volume explains how authoritarian regimes were studied in the past and how this may contrast with how authoritarian regimes are studied today. This compilation also examines the newest trends in authoritarianism in the 21st century and showcases interesting works on elections, media pluralism and regime hybridity. The volume also highlights the challenges posed by authoritarian regimes to the international order and the growing influence of authoritarian regimes.
\end{abstract}

\section{Keywords}

authoritarian elections; authoritarian regimes; hybrid regimes; totalitarian regimes

\section{Issue}

This editorial is part of the issue "Authoritarianism in the 21st Century", edited by Natasha Ezrow (University of Essex, UK).

(C) 2018 by the author; licensee Cogitatio (Lisbon, Portugal). This article is licensed under a Creative Commons Attribution 4.0 International License (CC BY).

Though most academic studies of politics have focused on democracy, the past fifteen years has seen a huge upsurge in academic work on authoritarian regimes. In the past the study of authoritarian regimes led to broad generalizations about these regimes. Though some of these stereotypes hold, they do not accurately depict all regimes.

No longer shrouded in mystery, many scholars have uncovered the ways in which authoritarian regimes differ and how these differences can lead to a range of outcomes.

Studies of authoritarian regimes of the past focused mostly on whether regimes were totalitarian or authoritarian. As such the key questions in studying dictatorships was how brutal the regime was, how it rose to power and how it exerted its will over the people. Totalitarian regimes a-special subset of authoritarian regimes that held complete power over its brainwashed citizens-were written about as if they were abundant. In totalitarian regimes there were no elections, the media was completely under state control and state propaganda was used to activate the citizens into loyal foot soldiers for the regime. Key examples studied were mostly found in Eastern Europe including the Soviet Union, East Germany, Albania and Romania. All other authoritarian regimes that were not totalitarian were lumped into a large category. These authoritarian regimes focused on creating an apathetic public that had no interest in involving themselves in the affairs of the state.

The level of brutality in totalitarian and authoritarian regimes of the past was also notable. Totalitarian regimes such as Uruguay (1973-1984) had a high percentage of political prisoners. Authoritarian regimes such as Iraq under Saddam Hussein (1979-2003) and Argentina under the military junta (1976-1983) brutally killed many of its own citizens. But today totalitarian regimes are almost extinct, with the one lone survivor being North Korea. The level of brutality of authoritarian regimes in general has also dissipated, as regimes have found other means to hold power effectively, without resorting to killing and controlling their citizens.

Generalizations of authoritarian regimes of the past also focused on their unpredictable nature. Authoritarian regimes such as Uganda under Idi Amin (1971-1979) made decisions on a whim, never considering the advice of technocrats or experts. Case in point, in early of August 1972, Amin ordered the expulsion of the Asian minority, given them only 90 days to leave the country. Studies of authoritarian regimes also focused on their eccentricities. Saparmurat Niyazov the former leader of Turkmenistan, for example, named the months and days of the week after himself and his family. Bal- 
let was banned because he found it dull. A course in the Rukhnama, a book of spiritual musings penned by Niyazov, was required to receive a driver's license (Blank, 2007; Polese \& Horák, 2015). Similarly, Kim Jong-il, former leader of North Korea used to travel in armoured trains, due to a fear of flying, and had lobsters air-lifted to him daily while he travelled. His son and current leader, Kim Jong-un travels with his own toilet. Muammar Gaddafi forced every Libyan to own chickens, even those living in small apartments. Every Libyan citizen was also forced to read his self-penned Green Book which outlined his philosophies. Though there are still some authoritarian regimes that are brutal, unpredictable and eccentric, there are also authoritarian regimes like that of Singapore, which are reasonable, stable and on most days may seem like a democracy.

In spite of these interesting anecdotes, much of the study of authoritarian regimes was unknown. One reason for this is that the study of authoritarian regimes is difficult. This area of research presents us with unique challenges because of the very fact that they are authoritarian. An extreme example of this is the case of Laos, a single-party dictatorship. For many years in Laos, even the identity of the party leaders was unknown. In some dictatorships, obtaining the most basic facts about the regime is impossible. Because of this, testing hypotheses regarding dictatorial political systems can be difficult. In spite of this, new studies of authoritarian regimes have been able to go beyond the classification that characterized regimes as either totalitarian or authoritarian and the old stereotypes of the past. New typologies of authoritarian regimes have shed light on who holds power, focusing on how that may impact the propensity for conflict, stability and development. Work has examined the factors that cause authoritarian regimes to breakdown and the mode of transition (Geddes, 1999, 2004).

While the last twenty-five years led to a mushrooming of studies focusing on authoritarian regimes, the 21st century has brought new forms of authoritarianism to examine. Post-Cold War authoritarian regimes are lasting in office longer than their predecessors. From 1946 to 1989 , the average duration of authoritarian regimes was 12 years. Since the end of the Cold War this number has almost doubled to an average of 20 years. Today, the typical dictatorship has been in power for 25 years. Iran's theocratic regime, for example, has ruled for 39 years-since the fall of the Shah in 1979. And the Cuban regime has maintained power for 42 years, riding out the 2008 transition of power from Fidel Castro to his brother Raúl. Learning from the mistakes-and successes-of their predecessors and peers, autocrats are altering their tactics to increase the durability of their regimes. The longevity and tactics of authoritarian rule has been one of the major areas of research of the past few decades.

This edited volume examines the newest trends in authoritarianism in the 21st century, namely the ways in which authoritarian regimes function today in light of greater scrutiny on sham elections, and greater power of the media. How do authoritarian regimes use elections to sustain their power and legitimacy and is this effective? How much media pluralism do authoritarian regimes actually offer? And, given that most authoritarian regimes have adopted elections and some media pluralism, many authoritarian regimes may actually fit in the hybrid category. In light of this, what are new ways for us to study hybrids to offer a better understanding about how they function? The volume offers a better understanding of not only the institutions in authoritarian regimes but the how these institutions affect citizen perceptions of what authoritarianism is. The volume also explains the challenges posed by authoritarian regimes and authoritarian styles of rule to the international order.

To provide a useful starting point, the first article by Erica Frantz (2018) presents an overview of the field of authoritarian regimes, offering a history of the key studies in authoritarian research and how the study of authoritarian regimes has changed over time. The article examines the study of totalitarian regimes, which was then followed by the emergence of single party, military and personalist regimes. The article also highlights the two major debates in the field: how to measure and categorize authoritarian regimes and whether or not pseudo-democratic institutions help authoritarian regimes survive.

In many cases, authoritarian regimes have been adaptable, using democratic institutions to sustain their rule indefinitely (Levitsky \& Way, 2012; Slater \& Fenner, 2011). As authoritarian regimes have moulded themselves to appear more democratic, this has also impacted citizens. Many citizens of authoritarian regimes perceive that they are living in democracies. Authoritarian regimes are not only more resilient than ever before but they are better at concealing their authoritarian nature.

Some authoritarian regimes have engaged in cosmetic democratization. After decades of near total control over its citizens the military regime in Myanmar unilaterally decided to embark on the path to political liberalization by holding relatively free and fair elections in 2010. But these democratization efforts masked a strong military that continues to rule behind the scenes and remains brutally repressive to the Rohingya minority. The example of Myanmar highlights an important trend in authoritarian regimes: holding elections without democratizing.

Elections are held by almost all authoritarian regimes, some of which are free of massive fraud. Elections are no longer an institution in which democracies hold a monopoly. But when elections are held by authoritarian regimes it is not a sign that genuine democratization is taking place. Rather elections are a tool used by authoritarian regimes in order to prolong their rule. In spite of this, studying elections in authoritarian regimes is a useful exercise. As the second article by John James Kennedy, Hongyan Liu, and Haruka Nagao (2018) indicates, the Chinese government has invested time and en- 
ergy into promoting voting in local elections as a civic duty of its citizens. Though China holds no national elections, studying its local elections is a way to gain further knowledge about how much support the regime has, and where the regime receives its strongest support.

In addition to being proficient at using elections to their advantage, some authoritarian regimes have become adept at using the media more creatively than in the past. Rather than completely controlling the media, some authoritarian regimes have figured out ways in which to allow some limited forms of media pluralism, at least in name. The third article in this edited volume, by Andreas Heinrich and Heiko Pleines (2018) explains the role of the media in authoritarian regimes in three staunchly authoritarian post-Soviet states: Azerbaijan, Kazakhstan and Turkmenistan. In all of these cases the media appears to be more pluralistic than it is in reality. Whereas past authoritarian regimes made no effort to appear to have limited pluralism, new authoritarian regimes pay lip service to this concept, but don't allow the opposition much leeway.

By offering limited pluralism of the media and civil liberties, holding elections and allowing some space for the opposition a new category of authoritarian regimes has emerged. The most recent wave of democratization has resulted in the proliferation of regimes that are neither fully democratic nor classically authoritarian. In today's day and age most regimes defy these binary categories. Though not all studies of authoritarian regimes consider the regimes that are stuck in the grey zone, the study of hybrid regimes is a topic where there is a growing interest. Initially mentioned almost thirty years ago, hybrid regimes are a "functional and territorial political mix" (Karl, 1995, 83). Hybrid regimes are a distinct subset from flawed democracies which are actually democratic but have certain defects that affect how they function. Hybrid regimes are often considered to be authoritarian regimes that have some democratic features. The fourth article, by Mariam Mufti (2018), examines the research on hybrids and argues in favour of moving away from only looking at elections to measure hybrids, and adopting a multi-dimensional assessment.

The growth of hybrids and flawed democracies around the world has led to concerns about the waning strength of democracy. The final article by Thomas Ambrosio (2018) explains the spread of authoritarian norms and the erosion of democratic legitimacy. The rise in power of Russia under Putin and China under Xi Jinping has signalled a shift in the normative structure of the international system. Democracy is no longer the dominant paradigm, and authoritarian regimes have increasingly more soft power. The rise of right-wing populist parties and leaders has also tapped into the growing dissatisfaction about democracy and a growing will for authoritarian models of governance.

In spite of these trends, the world still lives mostly in democratic governments; democracy is not going to dis- appear any time soon. However, these new models of authoritarianism that no longer exercise power in a totalitarian fashion, and are able to use and exploit democratic institutions for their longevity, pose a serious threat to democracies and to the democratic world order. Understanding more about the world of authoritarian regimes and hybrids helps us to better identify the challenges facing worldwide democracy and how and if to respond to them.

\section{Acknowledgments}

I would like to thank the editorial team at Politics and Governance.

\section{Conflict of Interests}

The author declares no conflict of interests.

\section{References}

Ambrosio, T. (2018). Authoritarian norms in a changing international system. Politics and Governance, 6(2), 120-123.

Blank, S. J. (2007). Turkmenistan and central Asia after Niyazov. Carlisle, PA: Army War College.

Frantz, E. (2018). Authoritarian politics: Trends and debates. Politics and Governance, 6(2), 87-89.

Geddes, B. (1999, September). Authoritarian breakdown: Empirical test of a game theoretic argument. Paper presented at the Annual meeting of the American Political Science Association, Atlanta, USA.

Geddes, B. (2004). Authoritarian breakdown. Los Angeles, CA: UCLA.

Heinrich, A., \& Pleines, H. (2018). The meaning of 'limited pluralism' in media reporting under authoritarian rule. Politics and Governance, 6(2), 103-111.

Karl, T. L. (1995). The hybrid regimes of Central America. Journal of Democracy, 6(3), 72-86.

Kennedy, J. J., Liu, H., \& Nagao, H. (2018). Voting and values: grassroots Elections in rural and urban China. Politics and Governance, 6(2), 90-102.

Levitsky, S. R., \& Way, L. A. (2012). Beyond patronage: Violent struggle, ruling party cohesion, and authoritarian durability. Perspectives on Politics, 10(4), 869-889.

Mufti, M. (2018). What do we know about hybrid regimes after two decades of scholarship? Politics and Governance, 6(2), 112-119.

Polese, A., \& Horák, S. (2015). A tale of two presidents: Personality cult and symbolic nation-building in Turkmenistan. Nationalities Papers, 43(3), 457-478.

Slater, D., \& Fenner, S. (2011). State power and staying power: Infrastructural mechanisms and authoritarian durability. Journal of International Affairs, 65(1), 15-29. 


\section{About the Author}

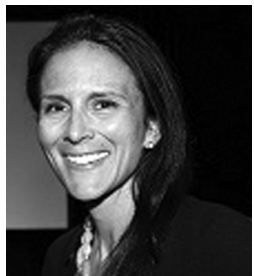

Natasha Ezrow is a Professor of Government at the University of Essex, where she serves as the Director of Education. She specializes in authoritarian regimes, corruption and failed states and has written several books on these topics including a forthcoming book titled Democracies and Autocracies. In addition to research, she enjoys teaching modules in the areas of International Development and Comparative Politics. 